\title{
WELVAART
}

\section{PERAN KEPALA DESA DALAM UPAYA MENYEJAHTERAKAN MASYARAKAT DESA PULAU TIGA KECAMATAN MENUI KEPULAUAN KABUPATEN MOROWALI}

Musniwati Harsoyo, Dewi Anggraini, Aryuni Salpiana Jabar Fakultas Ilmu Sosial dan Ilmu Pilitik Universitas Halu Oleo Email: musniwatiharsoyo07@gmail.com Korespondensi: Aryuni Salpiana Jabar

Email: aryunijabar@gmail.com

\begin{abstract}
ABSTRAK
Tujuan penelitian ini adalah 1) Untuk mengetahui peran Kepala Desa dalam upaya mensejahterakan masyarakat di Desa Pulau Tiga Kecamatan Menui Kepualauan Kabupaten Morowali 2) Untuk mengetahui faktor-faktor yang mempengaruhi pelaksanaan peran Kepala Desa dalam upaya mensejahterakan masyarakat di Desa Pulau Tiga Kecamatan Menui Kepulauan Kabupaten Morowali. Sumber data dalam penelitian ini menggunakan data primer yang didukung oleh data sekunder. Penelitian ini merupakan deskriptif kualitatif. Teknik pengumpulan data yang digunakan adalah wawancara, observasi dan dokumentasi. Pemerikasaan keabsahan datanya menggunakan teknik triangulasi teknik analisis data yang digunakan yaitu teknik analisis deskriptif kualitatif. Hasil dari penelitian menunjukan bahwa terdapat peran Kepala Desa dalam upaya mensejahterakan masyarakat di Desa Pulau Tiga Kecamatan Menui Kepulauan Kabupaten Morowali melalui penyelenggaraan pemerintahan dibidang administarasi kependudukan, melaksanakan pembangunan pada bidang perumahan dan bidang pendidikan, melaksanakan pembinaan kemasyarakatan pada bidang keagamaan, dan pemberdayaan masyarakat pada bidang pemberdayaan keluarga. Adapun faktorfaktor yang mempengaruhi pelaksanaan peran kepala desa yaitu terdapat faktor pendukung dang faktor penghambat.
\end{abstract}

Kata Kunci: Peran, Kepala Desa, Kesejahteraan Masyarakat

\section{PENDAHULUAN}

Negara Indonesia merupakan Negara kesatuan yang menggunakan sistem Demokrasi yang dimana kepemimpinannya diawali dari tingkat Negara, Provinsi, Kabupaten, Kecamatan dan Kelurahan/Desa. Bahwa dalam perjalanan Ketatanegaraan RI, Desa telah berkembang dalam berbagai bentuk sehingga perlu dilindungi dan diberdayakan agar menjadi kuat, maju, mandiri dan demokratis sehingga dapat menciptakan landasan yang kuat dalam melaksanakan pemerintahan dan pembangunan menuju masyarakat yang adil, makmur dan sejahtera. 


\section{WELVAART}

Adapun pemimpin yang tertinggi di Desanya yaitu disebut dengan Kepala Desa, dimana dapat melakukan pembaharuan pembangunan yang berdaya upaya melakukan tindakan-tindakan guna dalam upaya mensejahterakan masyarakat desa baik lahir maupun batin. Sebagai bentuk dari keinginan yang kuat untuk terus meningkatkan kesejahtraan masyarakat.

Kepala Desa juga merupakan penyelenggara dan sekaligus penanggung jawab atas jalannya roda pemerintahan dan pembangunan didalam wilayahnya. Di samping menjalankan urusan pemerintahan dan pembangunan, Kepala Desa juga mempunyai kewajiban lain yaitu menyelenggarakan urusan dibidang kemasyarakatan membina ketentraman dan ketertiban masyarakat serta membina dan mengembangkan jiwa dan semangat gotong royong masyarakat. Pelaksanaan pembangunan desa, sesuai dengan Peraturan Menteri Dalam Negeri Nomor 114 Tahun 2014 Tentang Pedoman Pembangunan Desa, sangat jelas disebutkan dalam pasal 1 ayat 9 bahwa: Pembangunan Desa adalah upaya peningkatan kualitas hidup dan kehidupan untuk sebesar-besarnya kesejahteraan masyarakat Desa. Selajutnya dalam asas pengeleloaan keuangan Desa pasal 2 ayat 1 dan 2 disebutkan bahwa: pemerintah desa menyusun perencanaan Pembangunan Desa sesuai dengan kewenangannya dengan mengacu pada perencanaan pembangunan Kabupaten/Kota, pembangunan desa sebagaimana dimaksud pada ayat (1) dilaksanakan oleh Pemerintah Desa dengan melibatkan seluruh masyarakat desa dengan semangat gotong royong.

Selain itu, kebijakan pembangunan di Indonesia terutama pembangunan Desa selalu bersifat top down dan sektoral dalam perencanaan serta implementasinya tidak terintegrasi, hal ini dapat dilihat dari program pemerintah pusat yaitu melalui setiap kementerian yang sifatnya sektoral. Perencanaan disusun tanpa melibatkan sektor yang lain serta pemerintah daerah, hal lain yang menjadi permaslahan adalah tidak dicermatinya persoalan mendasar yang terjadi di daerah, sehingga formulasi strategi dan program menjadi tidak tepat. Berkaitan dengan kemiskinan, sebagaimana terinformasikan dalam data statistik, ternyata sebagian besar masyarakat miskin berada di Desa. 


\section{WELVAART}

Oleh karena itu, pembangunan sudah sewajarnya difokuskan di Desa sebagai upaya mengatasi kemiskinan, pembangunan selama ini, lebih banyak di arahkan di Kota, hal ini menyebabkan aktivitas perekonomian, berpusat di Kota, hal inilah yang menyebabkan terjadinya migrasi dari Desa ke Kota. Masyarakat desa dengan segala keterbatasan pindah ke kota mengadu nasib dan sebagian besar dari mereka menjadi persoalan besar di kota. Disisi lain, kondisi di desa tidak tersentuh pembangunan secara utuh, infrastruktur dasar tidak terpenuhi, aktivitas ekonomi sangat rendah, peluang usaha juga rendah, sarana pendidikan terbatas, sebagian besar baru terpenuhi untuk sekolah dasar saja, Kondisi ini menyebabkan tidak ada pilihan lain bagi masyarakat desa untuk merubah nasibnya, yaitu dengan merantau ke kota.

Program dan kegiatan yang dapat diperankan oleh Kepala Desa, yaitu antara desa satu ke desa yang lainnya adalah terkait dengan peningkatan kesejahteraan, pengurangan kemiskinan, peningkatan kualitas sumber daya manusia dan pelibatan masyarakat dalam proses pengelolaan pembangunan perdesaan. Perlu diketahui bahwa hakikat pembangunan nasional yang komperhensif adalah meletakkan fondasi atau penopang yang kokoh pada pembanguna di wilayah perdesaan. Kesenjangan antara kawasan perkotaan dan perdesaan serta kemiskinan di perdesaan juga telah mendorong percepatan pembangunan di kawasan perdesaan dengan berbagai upaya.

Dengan demikian peran Kepala Desa sangatlah penting untuk memberikan perubahan di dalam masyarakatnya sehingga peran Kepala Desa yang telah dilakukan pada tahun 2016 sampai tahun 2018 Kepala Desa Pulau Tiga Kecamatan Menui Kepulauan Kabupaten Morowali telah melaksanakan perannya dengan melakukan pembangunan baik berupa fisik maupun non fisik yang dimana sumber dana dari pembangunan yang di peroleh Kepala Desa melalui dari Anggaran Dana Desa (ADD) yang bertujuan untuk meningkatkan kesejateraan masyarakat. Adapun peran Kepala Desa yang telah terealisasikan di Desa Pulau Tiga yaitu sebagai berikut : Pembangunan gedung TK \& PAUD, pembangunan Gedung Olahraga, Pemberian Rumah Layak Huni, TPA (Tempat Pendidikan Al Qur'an), pemberian mesin katinting, Perahu, Alat Pancing. 


\section{WELVAART}

Desa Pulau Tiga Kecamatan Menui Kepulauan kabupaten Morowali merupakan Desa yang dihuni oleh 3 suku yaitu: Bajo, Bugis dan Buton tetapi bahasa sehari-hari yang digunakan adalah bahasa Bajo atau sama walaupun mayoritas penduduk sebenarnya adalah suku Bugis tetapi masyarakat disana telah mengakui dirinya sebagai orang Bajo atau sama dikarenakan aktivitas yang mereka lakoni dalam sehari-hari yaitu aktivitas orang pesisir, Desa ini memiliki luas 4,985255 hektar dan berada dalam zona WITA (Waktu Indonesia Bagian Tengah) serta memiliki banyak penduduk sebesar 824 jiwa yang terdiri atas 223 kepala keluarga (KK).

Masyarakat yang ada di Desa Pulau Tiga, sebagian besar masyarakatnya bekerja sebagai nelayan dikarenakan potensi sumber daya alam yang sangat memadai dan juga sumber daya manusia yang sangat mendukung. Namun dalam tingkat pendidikan yang ada disana dari tahun 70an sampai tahun 2016 yang ada hanya Sekolah Dasar (SD) tetapi dengan pergantian kepemimpinan yang dimana Desa Pulau Tiga memiliki Kepala Desa yang baru sehingga banyak terjadi perubahan dalam upaya meningkatkan kesejahteraan masyarakat. Melalui pembangunan baik yang berupa fisik maupun non fisik, hal ini agar dapat membantu masyarakat Desa Pulau Tiga terhindar dari kebodohan dan kemiskinan.

Setelah menguraikan latar belakang penulis menemukan beberapa penelitian terdahulu yang mengkaji tentang Kepala Desa yang kemudian dijadikan kajian maupun sesuatu yang diangkat oleh penulis, penelitian tersebut antara lain:

Penelitian oleh Mahmudi yang berjudul "Peran Pemerintah Desa Terhadap Pos Pemberdayaan Keluarga di Desa Brosot Kecamatan Galur Kabupaten Kulon Progo Ditinjau Dari Inpres No. 3 Tahun 2010”. Penelitian ini menjelaskan implementasi Inpres No. 3 Tahun 2010 tentang peran pemerintah desa di Desa Brosot Kecamatan Galur Kabupaten Kulon Progo. Hasil penelitian ini adalah pemerintah mengimplementasikan Inpres No. 3 Tahun 2010 melalui POSDYA dengan berupaya penuh dengan mewujdkan sumber daya manusia yang sehat demi tercapainya keluarga sejahtera.

Penelitian oleh Sony Kristianton dengan judul "Peran Pemerintah Desa Dalam Meningkatkan Pemberdayaan Masyarakat di Desa Lindung Kemenci 


\section{WELVAART}

Kecamatan Mentarang Kabupaten Malinau”. Metode pengumpulan data yang dipakai adalah kepustakaan dan lapangan seperti observasi, wawancara, dan dokumentasi. Teori yang digunakan adalah pengertian peran, peran kepala desa, pengertian desa, serta pemberdayaan masyarakat. Hasil penelitiannya adalah gambaran secara keseluruhan dari peran kepala desa cukup baik. Peran tersebut terlihat dalam hal menampung dan menyalurkan aspirasi masyarakat, penyusunan kegiatan pembangunan secara partisipatif, berswadaya dan gotong royong, serta menggali dan memanfaatkan sumberdaya potensi yang ada untuk kepentingan pembangunan di Desa.

Berbeda dengan penilitian terdahulu yang telah dipaparka oleh penulis di latar belakang, maka menarik perhatian penulis untuk melakukan penelitian yang berjudul "Peran Kepala Desa Dalam Upaya Mensejahterakan Masyarakat (Studi di Desa Pulau Tiga Kecamatan Menui Kepulauan Kabupaten Morowali Sulawesi Tengah)".

\section{METODE}

Penelitian ini telah dilaksanakan di Desa Pulau Tiga Kecamatan Menui Kepulauan Kabupaten Morowali. Alasan peneliti melaksanakan penelitian di Desa Pulau tiga karena telah banyak pembangunan yang terealisasikan oleh peran Kepala Desa, yang di mana peneliti bisa melihat bahwa Kepala Desa Pulau Tiga banyak berperan aktif dalam upaya mensejahterakan masyarakat.

Informan dalam penelitian ini sebanyak 17 orang yang merupakan Kepala Desa, Aparat Desa, sekretaris, bendahara, tokoh agama dan masyarakat setempat yang ada di Desa Pulau Tiga. Teknik penentuan informan ini dilakukan secara purposive sampling yaitu suatu teknik penentuan informan secara disengaja dengan tujuan untuk memudahkan peneliti untuk memperoleh data atau informasi yan didasarkan ciri-ciri, sifat, atau karakteristik tertentu yang sudah ditetapkan. Karakteristik atau kriteria penentu informan yang dilakukan dalam penelitian yaitu pihak-pihak yang terkait dalam peran Kepala Desa Pulau Tiga Kecamatan Menui Kepulauan Kabupaten Morowali.

Teknik analisis data yang digunakan dalam penelitian ini adalah dengan menggunakan teknik analisis deskriptif kualitatif, dimana data yang diperoleh 


\section{WELVAART}

disajikan dalam bentuk penjelasan, uaraian, dan menggambarkan kondisi sesungguhnya. Menurut Arikunto (1989) analisa kualitatif digambarkan dengan kata-kata atau kalimat yang dipisahkan menurut kategori untuk memperoleh kesimpulan dan diangkat dan sekedar mempermudah dua penggabungan variabel selanjutnya dikualifikasi kembali. Setelah data tersebut diolah kemudian dapat dianalisa dengan menggunakan data induktif, yaitu berangkat dari fakta-fakta dan peristiwa-peristiwa kongkrit dan tarik kesimpulan yang bersifat umum ke khusus.

\section{HASIL DAN PEMBAHASAN}

Peran Kepala Desa Dalam Upaya Mensejahterakan Masyarakat Di Desa Pulau Tiga Kecamatan Menui Kepulauan Kabupaten Morowali

\section{Menyelenggarakan Pemerintahan Desa Di Bidang Administrasi}

\section{Kependudukan}

Kepala Desa bahwa penyelenggaraan Pemerintahan Desa di bidang administrasi kependudukan ini yaitu masyarakat yang belum memiliki eKTP, KK dan Akta lahir.

2. Melaksanakan Pembangunan Pada Bidang Perumahan dan

\section{Pendidikan}

\section{a) Bidang Perumahan}

Kepala Desa Pulau Tiga melalui anggaran Dana Desa (DD) memberikan bantuan perumahan pada tiap-tiap warga yang kondisi rumahnya tidak layak lagi untuk dihuni. Setiap warga yang mendapatkan bantuan perumahan harus di dokumentasikan agar bisa menjadi bukti untuk dibawa ke kabupaten, adapan warga yang mendapatkan rumah layak huni sebanyak 14 unit yang kebnyakan penerimanya dari kalangan jandajanda serta setiap warga yang mendapatkan bantuan perumahan ini tidak diberikan secara langsung uang kes melainkan mereka diberikan langsung bahan bangunan rumah agar mereka tidak merasa kesulitan lagi membeli bahan bangunan rumah.

\section{b) Bidang Pendidikan}




\section{WELVAART}

pembangunan pendidikan seperti gedung TK, Kepala Desa berharap agar dengan adanya sekolah TK ini dapat diterima dengan baik oleh semua warga masyarakat yang ada di Desa Pulau Tiga.

\section{Melaksanakan Pembinaan Kemasyarakatan Pada Bidang}

\section{Keagamaan}

peran Kepala Desa dibidang keagamaan yaitu pemberian fasilitas kegiatan keagamaan seperti penambahan alat-alat ceramah, pemberian pakaian untuk ibu-ibu majelis taqlim selain itu pula kepala Desa Pulau Tiga mendatangkan penceramah dari luar untuk di jadikan guru agama/ustadz agar bisa mengajar dan mendidik anak-anak, remaja maupun Ibu-ibu yang ada di Desa Pulau Tiga serta bisa memberikan wawasan sekaligus pemahaman yang baik tentang agama islam.

\section{Pemberdayaan Masyarakat Pada Bidang Pemberdayaan Keluarga}

permberdayaan keluarga khususnya keluarga nelayan yaitu dilakukan dengan cara pemberian perlengkapan nelayan melalu Anggaran Dana Desa (ADD) seperti pemberian perlengkapan melaut yaitu mesin katinting dan sampan bagi warga yang kurang mampu untuk dapat lebih bersemngat dalam mencari nafkah dilaut. Pemberian bantuan mesin katinting dan sampan ini sangat membantu warga masyarakat, khususnya kepada keluarga nelayan yang mata pencahariannya dilaut.

Faktor-faktor Yang Mempengaruhi Pelaksanaan Peran Kepala Desa Dalam Upaya Mensejahterakan Masyarakat di Desa Pulau Tiga kecamatan Menui Kepulauan Kabupaten Morowali

\section{a. Faktor Pendukung}

\section{1) Keturunan}

Keturunan bagi masyarakat Desa merupakan hal yang perlu diperhatikan jika hendak melaksanakan perannya sebagai seorang Kepala Desa, karena di dalam masyarakat Desa masih terdapat sekelompok masyarakat yang senantiasa mempertahankan nilai-nilai dan norma-norma masyarakat yang masih sangat kental. 


\section{WELVAART}

\section{2) Kewibawaan}

Untuk menopang kedudukannya sebagai pemimpin, maka kepala desa haruslah memiliki wibawa baik terhadap bawahannya maupun di mata masyarakatnya. Namun bukan berarti kewibawaan harus membatasi diri terhadap masyarakat, tetapi bagaimana memberi pandangan kepada masyarakat bahwa sebagai seorang pemimpin ia harus memiliki wibawa.

\section{3) Kekuasaan}

Kekuasaan adalah kekuatan, legalitas, dan otoritas yang memberikan wewenang kepada pemimpin guna mempengaruhi dan menggerakkan bawahan untuk berbuat sesuatu. Tanpa kekuasaan bagaimana mungkin seorang pemimpin mampu menjalankan tugasnya karena hanya dengan kewenanganlah seseorang berhak memerintah orang lain.

\section{b. Faktor Penghambat}

\section{1) Kondisi Penduduk}

Sebagai pemimpin masyarakat, maka sudah selayaknya apabila seseorang kepala desa mengetahui kondisi atau keadaan masyarakat yang sebenarnya. Sebab dengan mengetahui kondisi masyarakat yang sebenarnya maka dapat mengambil langkah-langkah yang tepat dalam mengambil keputusan dan tindakan. Sebab bila pemimpin tidak mengetahui kondisi masyarakat maka akan menjadi suatu kesalah pahaman yang tidak dapat diterima oleh masyarakat.

\section{2) Partisipasi Penduduk}

Partisipasi merupakan komponen penting dalam menumbuh kembangkan kemandirian dan proses pemberdayaan. Rakyat adalah komponen utama yang harus dilibatkan dalam setiap proses pembangunan. Kebutuhan, kepentingan dan harapan rakyat menjadi arah setiap kebijakan. Prinsip dalam partisipasi adalah melibatkan atau peran serta masyarakat secara langsung, dan hanya mungkin dicapai jika masyarakat sendiri ikut ambil bagian, sejak dari awal, proses, dan perumusan hasil.

\section{3) Fasilitas atau Peralatan}




\section{WELVAART}

Untuk melaksanakan tugasnya, pemerintah desa membutuhkan fasilitas atau peralatan dalam menjalankan fungsinya, tersedianya fasilitas atau perlengkapan yang tersedia menunjang lancarnya suatu kegiatan yang akan dilaksanakan, dimana salah satu faktor itu adalah tersedianya kantor desa dalam menunjang terselenggaranya pemerintahan desa dan sebagai tempat dalam menjalankan tugas dalam pengelolaan, pelaporan, pencatatan, dan berbagai kegiatan lainnya. Kegiatan pemberdayaan masyarakat dipengaruhi oleh ketersedianya fasilitas atau peralatan, misalnya dalam rapat desa dan kegiatan penyuluhan perikanan akan berjalan lancar jika tersedianya tempat beserta peralatan tulis menulis misalnya papan tulis (black board), LCD, dan infocus yang digunakan dalam rapat dan penyuluhan.

\section{KESIMPULAN}

Mengenai Peran Kepala Desa dalam Upaya Mensejahterakan Masyarakat di Desa Pulau Tiga Kecamatan Menui Kepulauan Kabupaten Morowali, yaitu dapat disimpulkan bahwa sebagai berikut :

1. Peran Kepala Desa dalam upaya mensejahterakan masyarakat di Desa Pulau Tiga Kecamatan Menui Kepulaun Kabupaten Morowali, yaitu 1) Menyelenggarakan pemerintahan Desa di bidang administrasi Kependudukan seperti halnya eKTP, KK dan Akta lahir. 2) Melaksanakan pembangunan pada bidang perumahan dan bidang pendidikan yaitu pemeberian bantuan perumahan layak huni dan pembangunan gedung TK melalui Anggaran Dana Desa (ADD). 3) Melaksanakan pembinaan kemasyarakat pada bidang keagamaan. 4) Pembinanaan masyarakat pada bidang pemberdayaan keluarga nelayan yaitu pemberian bantuan mesin katinting dan penyuluhan perikanan

2. Faktor-faktor yang mempengaruhi pelaksanaan Peran Kepala Desa dalam upaya mensejahterakan masyarakat di Desa Pulau Tiga Kecamatan Menui Kepulauan Kabupaten Morowali, yaitu a. Faktor Pendukung : 1) Keturunan yang dimaksud disini adalah sosok pemimpin dari keluarga baik-baik sehingga ia memperoleh pengakuan dari masyarakat. 2) Kewibawaan adalah kekuatan yang terpancar dari diri seorang Kepala Desa. 3) Kekuasaan adalah kekuatan, legislates dan otoritas seorang pemimpin. b Faktor Penghambat : 1) Kondisi 


\section{WELVAART}

JURNAL ILMU KESEJAHTERAAN SOSIAL

http://ojs.uho.ac.id/index.php/WELVAART

penduduk yang majemuk dan sulit untuk menerima perubahan. 2) Partisipasi penduduk adalah keikutsertaan masyarakat 3) Fasilitas atau peraralatan yang dimaksud seperti ATK/alat tulis komputer.

\section{DAFTAR PUSTAKA}

Adisasmita, Rahardjo. 2006. Pembangunan Perkotaan dan Perkotaan. Graha Ilmu Yogyakarta.

Anwar, 2005, Konsep Pembangunan Desa. Jakarta, Gramedia

Achmadu, 2002, Pedesaan Fokus Pembangunan, Jakarta, Prisma.

Abdullah, 2003 Jalan Menuju Stabilitas. Mencapai Pembangunan Ekonomi Berkelanjutan. PT Pustaka LP3ES Indonesia, Jakarta.

Arikunto, Suharsini, Prosedur Penelitian. (Jakarta: Rineka Cipta, 1989).

Bintoro, Tjokroamidjojo. 2004. Pengantar Administrasi Pembangunan. LP3ES, Jakarta.

BKKBN, 1993, Petunjuk Teknis Pencatatan dan Pelaporan Pendataan Keluarga Sejahtera Gerakan KB Nasional, BKKBN Pusat, Jakarta.

Echlos, John M and Hassan Shadhily 2000. Kamus Inggris-Indonesia. Jakarta: Gramedia Pustaka Utama.

Midgley, James. 1995. Social Development: the Developmental Perspective in Social Wlfare. London: Sage Publications Ltd.

Mahmudi, Peran Pemerintah Desa Terhadap Pos Pemberdayaan Keluarga di Desa Brosot Kecamatan Galur Kabupaten Kulon Progo Ditinjau Dari Inpres No.3 Tahun 2010, (Skripsi Jurusan Ilmu Hukum, Fakultas Syari'ah dan Hukum, UIN Kalijaga Yogyakarta, 2013)

Ndraha, Taliziduhu, 1990. Pembangunan Masyarakat Mempersiapkan Masyarakat Tinggal Landas. Jakarta: Rineka Cipta.

Riyadi, dkk., 2015. Indikator Kesejahteraan Rakyat 2015 (Welfare Indicators 2015). Jakarta: Badan Pusat Statistik (BPS).

Soni Kristianto, "Peran Pemerintah Desa Dalam Meningkatkan Pemberdayaan Masyarakat di Desa Lindung Kecamatan Mentarang Kabupaten Malinau”, Jurnal Ilmu Pemerintahan, fakultas ilmu sosial dan politik, Universitas Malawarman, Vol. $1: 2013$

Syamsiah, Badruddin. 2006. Dampak Globalisasi Terhadap Pembangunan Di Desa Berkembang. (Jurnal Edukasi, Bandung).

Soerjono, Soekanto, Sosiologi Suatu Pengantar (Jakarta: CV. Rajawali, 1986).

Soerdamayanti, (2007). Perilaku Peranan. Bandung. PT.Gramedia Pustaka, Jakarta.

Solekhan, Moch. 2014. Penyelenggaraan Pemerintahan Desa Berbasis Partisipasi Masyarakat. Malang: Setara Press.

Suharto, Edi., 2009, Membangun Masyarakat Memberdayakan Rakyat. Bandung: PT Refika Aditama.

Spicker, Paul. 1995. Principles of Social Welfare. London: Routledge. 


\section{WELVAART}

Sunyoto,

Usman.

(2004).

Pembangunandan

Pemberdayaan

Masyarakat.Yogyakarta: Pustaka Pelajar.

Upe, Ambo. 2016. Metode Penelitian Sosial. Kendari: Literacy Insitute.

Widjaja, HAW., 2012. Otonomi Desa Merupakan Otonomi yang Asli, Bulat dan Utuh. Jakarta: Rajawali Pers.

Zaini Mustakim, Mochammad., 2015. Kepemimpinan Desa. Jakarta: Kementerian Desa, Pembangunan Daerah Tertinggal dan Transmigrasi Republik Indonesia

\section{Undang-undang}

Undang-Undang Nomor 11 Tahun 2009 tentang Kesejahteraan Sosial.

Undang-Undang Nomor 23 Tahun 2014 tentang Pemerintahan Daerah.

Undang - Undang Nomor 6 Tahun 2014 tentang Desa..

Peraturan Menteri Desa, Pembangunan Daerah Tertingal, dan Trasmigrasi Republik Indonesia, Nomor 1 Tahun 2015 Tentang Pedoman Kewenangan Berdasarkan Hak Asal Usul dan Kewenangan Lokal Berskala Desa.

Peraturan Menteri Dalam Negeri Nomor 44 Tahun 2016 Tentang Kewenangan Desa.PP. no. 43 Tahun 2014 tentang Petunjuk Pelaksanaan UU Desa. 